\title{
Is this a Real Story? Learning Critical History and Learning Its Limits
}

Sam Wineburg

The study of history plays a central role in the Jewish educational curriculum.
But when we invite students to consider the Jewish past, what are we really after? In this chapter, Wineburg brings a self-critical perspective to the commitments that we might expect from him, as a leading researcher of the teaching and learning of history. Calling on some familiar examples of the tension between what the great Jewish historian Yosef Yerushalmi called "Jewish history" and "Jewish memory," he argues against the standard moves-some because they do not satisfactorily account for Jewish commitments, and others because they do not satisfactorily account for the absence of criteria of personal or national significance within academic history. Eschewing an easy or facile resolution of the problem, Wineburg sharpens it for us: how do we accommodate our interests and values, the very interests and values that bring us to a study of Jewish history, without compromising our intellectual integrity?

Passover marks the freedom of the Jewish people from Egyptian bondage. For four hundred years Pharaoh turned a deaf ear to the Hebrews' cries. Only when God intervened, raining down ten plagues like turning the Nile into blood and unleashing a torrent of frogs so that from every cooking pot and hearth, leaping frogs made daily life hell_-only then did Pharaoh relent and let the Hebrews go.

My family tells this story every spring. When our three children were young - too young to sit through a highly ritualized retelling-we would act out the story, one of us playing the brave Moses, another his arch rival Pharaoh, 
and others the Egyptian taskmasters who demanded that the Jews meet their brick quota or face the lash.

One year, when my youngest son Raphael was seven, he sat on my lap with rapt attention, without any of the visual aids or sit-com sketches that keep a child awake. He followed along in the Haggadah, the ancient record of this story. At the end of the evening, the Afikomen found, the fourth cup of wine emptied, Raphael started to nod off. As I picked him up to put him to bed, he awoke, startled. He was perceivably disturbed. By what I was not sure.

As I laid him to bed, he gazed at me, now wide-awake. Something was on his mind. Then, with the unalloyed innocence of a young child, he asked me this question: "Dad, what we read tonight, was that a real story?" It was past midnight and I was beat. I promised to get back to him in the morning. That morning has lasted sixteen years. I am still pondering Raphael's question.

Was he asking me, if you will, a question of narratology, a query that accents the word story? Did the Haggadah conform to what Aristotle in the Poetics described as the basic structure of story: a beginning, middle, and end, with a unity of plot and chains of cause and effect sequences? Did its tension state arc before reaching its climax?

If that was what my seven-year-old was asking, then my response should have been, yes, Raphael, this is a real story. This story, the Exodus tale, conforms to the dictates of narratology to a T. In fact, one might even call it a template for all kinds of stories. The Exodus has captured the imagination of generations precisely because of its power as story.

As you might imagine, however, I do not believe that this was what my son was asking.

Sometime between the ages of seven to ten, the child, according to Jean Piaget, transitions from concrete operations and begins to enter the corridor of mature adult thinking, the earliest stages of what he called "formal operations." It is a time when the child moves from a world of make-believe (in which make-believe seems real) to a time when magical thinking falls away and the child begins to see the world veridically. Raphael no longer believed me when I pointed upward and said, "Watch, I'll wipe my hand across the sky and make the sun go down." He already knew better.

1 See, for example, Jean Piaget, Science of Education and the Psychology of the Child (New York: Orion Press, 1970). 
What my son wanted to know was whether everything he had just heardabout a land called Egypt, about garrison cities of Pithom and Ramses (Exodus 1:11), about a ruler named Pharaoh and a rebellious leader of a slave revolt named Moses, about a mountain called Sinai, and a forty-year sojourn in the desert-whether this was a true story.

I believe my son's question came untouched by any postmodern taintthe notion that all stories are constructs, that they are fabricated from words, that there is, to invoke Jacques Derrida, nothing outside of the text. ${ }^{2}$ Raphael was blithely unaware, I believe, of Hayden White's Metahistory, which smudges the line between history and literature by contending that the historian must (in order to use the story form) emplot it, calling on conventions like irony, romance, or satire to give form to an otherwise meaningless sequence of events. ${ }^{3}$ Such determinations contrast with Leopold von Ranke's imperative to capture history as it really was ("wie es eigentlich gewesen"), ${ }^{4}$ and edge the historian closer to the novelist than to the scientist. Raphael was similarly unaware of Michel Foucault, who saw stories and those who stamped them on modern consciousness as tools of oppression, ways to seize and not let go of power by those in authority. ${ }^{5} \mathrm{No}$, my son's question was innocent of the anti-foundational undertones that have punctuated academic discourse during the last few decades.

Raphael, I believe, was asking a much more basic question. My son was only a child but he was not asking a childish question. In fact, it's a question that we ask too once we leave our ivied halls and resume our lives as neighbors, citizens, and ordinary people. When we watch Schindler's List or Seabiscuit or Selma, and describe the movie to our next-door neighbors and they ask, "Sounds fabulous, but is it a true story?," we know precisely what they mean. Maybe the filmmaker exaggerated; maybe people didn't die exactly in this way; maybe the clothing they wore was more modest than what some Hollywood costume designer dreamt up; maybe the relationship between Martin Luther King and Lyndon Johnson was more amiable than that portrayed on the

2 Jacques Derrida, Limited Inc. (Evanston, IL: Northwestern University Press, 1988), 144.

3 Hayden White, Metahistory: The Historical Imagination in 19th-century Europe (Baltimore, MD: Johns Hopkins University, 1973).

4 Leopold von Ranke, Geschichten der romanischen und germanischen Völker von 1494 bis 1535 (History of the Latin and Teutonic nations, 1494-1535) (Leipzig: Reimer, 1824), v-vi.

5 For example: "Interpretation is the violent or surreptitious appropriation of a system of rules .... in order to impose a direction, to bend it to a new will, to force its participation in a different game, and to subject it to secondary rules...." Michel Foucault, "Nietzsche, Genealogy, History [1971]," in The Foucault Reader, ed. Paul Rabinow (New York: Pantheon, 1984). 
screen. But a more fundamental question remains: Did Oskar Schindler really manage to save a thousand Jews from the gas chambers? Was there really a horse that at the height of the Depression won race after prestigious race and offered hope to a nation mired in economic despair? Or ... did the filmmaker "make it up?"

Such questions return us to the evening when Raphael, alternatingly nodding off and still very much awake, asked me if what he had just heard was a real story. In 2001, on Passover eve, Rabbi David Wolpe, the spiritual leader of Los Angeles's Temple Sinai, shocked his congregants by asking the same question from the pulpit. His sermon sent shock waves throughout the sanctuary and made such a ruckus that accounts appeared in newspapers from New York City to Jerusalem. "The truth is," said Wolpe, "that virtually every modern archeologist who has investigated the story of the Exodus, with very few exceptions, agrees that the way the Bible describes the Exodus is not the way it happened, if it happened at all." 6

"If it happened at all."

There you have it. Raphael's question answered. Not only did the Torah, and afterwards the Haggadah, screw up the details, but worse. It's not even clear that the whole thing happened at all.

All is not lost however. Wolpe's flock and my son Raphael could take solace in the fact that even if the Exodus had not occurred, even if the story was not "historically" true in the same way that there was a horse named Seabiscuit or a businessman named Oskar Schindler, it was true in other, more sublime, ways. The Exodus contains a "deeper and more central meaning." The story should be revered not because of its facticity but because it has "been regarded by past generations as true." 7 The real Egypt, in other words, is not a geographical territory running westward along the twenty-second parallel from the Red Sea. Rather, Egypt is a metaphor. As one of Wolpe's congregants put it: "We all have our own Egypts - we are prisoners of something, either alcohol, drugs, cigarettes, overeating. We have to use [the story] as a way to free ourselves from difficulty and make ourselves a better person."

After delivering his bombshell, Wolpe offered a follow-up sermon in which he distinguished historical truths from "spiritual truths" and why it's

6 David Wolpe, quoted in Teresa Watanabe, "Doubting the Story of Exodus," Los Angeles Times, April 13, 2001.

7 David Wolpe, quoted in Gustav Niebuhr, "Religion Journal; A Rabbi’s Look at Archaeology Touches a Nerve," New York Times, June 2, 2001.

8 Watanabe, "Doubting the Story of Exodus." 
important not to get the two mixed up. ${ }^{9}$ Wolpe's sermon had the feeling of a parent breaking the news to a child about make-believe. Fairy tales may serve a developmental need, but carried into adulthood they stunt maturation. Grow up, he seemed to say to his flock. "You do not serve God if you do not seek truth." ${ }^{10}$ In this case, it was clear which truth Wolpe meant.

By drawing on the modern science of archeology, history, and the social sciences, Wolpe ushered his congregants into the modern era, following a tradition that goes back to Baruch Spinoza. Sitting in his Amsterdam study in 1655, Spinoza used the tools of philology to question the Mosaic authorship of the Torah, setting into motion a movement that emerged in the early nineteenth century as Wissenschaft des Judentums, the scientific study of Judaism.

Wissenschaft drove a wedge between the stories of Jewish tradition and accounts that survived rational analysis of a new cadre of Jewish historians, archeologists, and geographers. Historical understanding was the fruit of a painstaking process of locating events in temporal contexts, and trying to reconstruct the assumptions, beliefs, and worldviews of past actors living at particular moments. The discipline of history progressed haltingly but steadily. Scientific history drew inspiration from the precision and exactitude of the natural sciences rather than the humanistic traditions of literature, poetry, and art. It was said of von Ranke that he would "cross an ocean to verify a comma."

Wissenschaft was on a collision course with traditional conceptions of the Jewish past. The rift was irreparable. Yosef Hayim Yerushalmi, the esteemed Columbia University historian, mournfully wrote that there was no way to pick up the pieces: "Jewish historiography [is] divorced from Jewish collective memory and, in crucial respects, thoroughly at odds with it." 11 The historian, and perhaps especially the Jewish historian, can be no sentimentalist whose job it is to "replenish gaps of memory." 12 If they are to have integrity as scholars, historians must play by the rules of the academy. Without malice or ill intent, they must follow the scent of inquiry wherever it led. The responsible

9 “L.A. Rabbi Blasted for Fifth Question: Was There Really a Passover Exodus?” Jewish Telegraphic Service, April 27, 2001, http://www.jta.org/2001/04/27/jewish-holidays/passover/l-a-rabbi-blasted-for-fifth-question-was-there-really-a-passover-exodus.

10 Watanabe, "Doubting the Story of Exodus."

11 Yosef Hayim Yerushalmi, Zakhor: Jewish History and Jewish Memory (New York: Schocken, 1989), 94.

12 Ibid. 
historian, wrote Yerushalmi, "challenges even those memories that have survived intact."13

Which brings us back to Raphael's question. Across the denominational divide, parents send their children to Jewish schools with certain hopes and dreams. They want their children to emerge from Jewish schooling with strong Jewish identities. They want their children to understand that against all odds, the Jewish people have endured throughout the ages, and thrived. They hope that their children will come to see the stories of the Jewish people as their own. They hope their children will learn that they are part of a chain that binds them to their ancestors and prepares them for the future. If Yerushalmi is right and history destroys without malice, what role is left for it the curriculum of the Jewish school?

One explicit answer comes from Robert Chazan, the Scheuer Professor of Hebrew and Judaic Studies at New York University, who put forth his vision in a 2010 article in HaYidion, the practitioner-oriented journal of "community" (i.e., non-denominational) Jewish day school movement. ${ }^{14}$ Like Wolpe, Chazan distinguishes between two ways of thinking about the past: "critical history" and what he termed "traditional thinking about the past." But whereas Wolpe dismantled the Exodus, Chazan takes a hatchet to Hanukkah. The story widely taught, of the wicked Antiochus, who defiled the Temple and forced the Jews to worship Greek gods, turns out to be an admixture of myth, half-truth, and distortion. Modern scholarship yields "no evidence whatsoever for such a Seleucid policy in any sector of the far-flung empire or at any time." Immortalized in songs, rituals, and insertions in the Siddur, Hanukkah is actually a bundle of twisted fictions. Critical history has "radically altered the traditional story," Chazan writes, "to the dismay of many Jews." And this is just the start.

Chazan is playing with dynamite and he knows it. He titles his article "Faith and Critical Jewish History: A Complex Relationship." He is aware that many parents see critical history as "corrosive," a threat to Jewish identity and thus a "disservice to young children enrolled in Jewish schools." He admits that such a charge - that critical history will weaken Jewish commitment-makes "prima facie" sense.

Prima facie. From the Latin, "on its face," or as we might say, "on the surface." In other words, when we examine the situation more closely, the charges

13 Yerushalmi, 94.

14 Robert Chazan, "Faith and Critical Jewish History: A Complex Relationship," HaYidion (2010), 50-53. 
against critical history are baseless. The deeper threat, Chazan warns, comes not when the Jewish school teaches critical history, but when it doesn't. Our students are born into a modern world. They will go off to college and be exposed to the tools of critical scholarship. Is it not preferable, Chazan asks, for students to be exposed to critical history "within the confines of Jewish education" rather than in a "less supportive environment"?

Notice, then, that the "complex relationship" referred to in Chazan's title has little to do with the history part of the equation, its epistemological assumptions, or how the discipline has responded to the challenges from an entourage of post-modernists, post-structuralists, anti-foundationalists, as well as from quarters within the discipline: social and micro-historians, feminist scholars and scholars of color, historians who study gay, lesbian, and transgender issues. ${ }^{15}$ For Chazan, critical history itself-its methodology, its claims to truth-is not at issue. Rather, the source of complexity is pedagogic.

How should educators reconcile critical history's blinding light with the tender minds and open hearts of young children? At what age should critical history be introduced? How do we ease the transition from "traditional thinking about the past" to an analytic approach that prepares students for the next stages of their education, as middle class American kids, at Brown or Wesleyan or Ohio State? Should critical history be dished out in small portions or should we tell children the truth right off the bat? Such questions, according to Chazan, demand "more nuanced and thoughtful deliberation."

Although Chazan does not invoke notions of psychological development, its timbre echoes between the lines. One is reminded of Ernst Haeckel's claim that "ontogeny recapitulates phylogeny," the idea that the development of the individual roughly parallels the evolution of the species. ${ }^{16}$ Our ancestors

15 It is beyond my scope to review all of the challenges to critical history, as Chazan portrays it. For an overview see Peter Novick, That Noble Dream: The "Objectivity Question" and the American Historical Profession (New York: Cambridge University Press, 1988). Perhaps the most powerful critique comes from Michel Foucault; an excellent introduction is Paul Rabinow's opening essay to The Foucault Reader. See Michael Foucault, et al., The Foucault Reader (New York: Pantheon Books, 1984). Evenhanded treatments of the epistemological challenges to history as "normal science" come from Richard Evans, In Defense of History (New York: W. W. Norton and Company, 1999), and Thomas Haskell, Objectivity is Not Neutrality: Explanatory Schemes in History (Baltimore, MD: Johns Hopkins, 1998). Finally, David N. Myers's brilliant Resisting History: Historicism and its Discontents in German-Jewish Thought (Princeton, NJ: Princeton University Press, 2003) is indispensable to anyone examining these issues from a Jewish perspective.

16 Ernst Haeckel, Generelle morphologie der organismen [General Morphology of the Organisms] (Berlin: G. Reimer, 1866). Haeckel is typically credited with the phrase, but it is unclear 
credulously accepted leaping frogs, manna dropping from Heaven, and a God who delivered his people from slavery. Successive generations believed these stories because their ancestors believed them and their ancestors' ancestors believed them. As science progressed, warranted knowledge displaced old stories. We can still cherish those stories because our forefathers cherished them-but we should not be confused. Whether we call such stories "spiritual history," "Midrash," or "traditional ways of thinking about the past," they are no substitute for the real thing. ${ }^{17}$ We must, according to Chazan, "communicate to the young student that the tradition puts a premium on mature reflection and valorizes intellectual engagement." In contrast to the assumptions of those who believe that critical history subverts traditional commitments, Chazan seems to propose that critical history is not just a necessary evil but in fact an important element of the process of development and maturation. In other words, if we want our children to grow up, they need the bone-strengthening sustenance of critical history.

What, then, are we to tell our students as they delve into the Jewish past in search of understanding the Jewish experience throughout the ages? Go ahead and light your Hanukah candles, but remember that Antiochus's downfall resulted from military miscalculations, overstretched forces, tactical errors, economic considerations, misplaced priorities, or any variety of causes-except the one recited during morning prayers during Hanukah: amade'ta la-hem ba'et tzaratam, "You stood by them in their hour of need"? ${ }^{18}$

What happens when one of our students, searching for a way to make sense of the sweep of Jewish history, stumbles across Mark Twain's 1899 essay, Concerning the Jews:

[The Jew] has made a marvelous fight in this world, in all the ages; and has done it with his hands tied behind him... The Egyptian, the Babylonian, and the Persian rose, filled the planet with sound and splendor, then faded ... the Greek and the Roman followed, and made a vast noise, and they

whether it actually originated with him. Regardless, as is well known, the theory of "recapitulation" is not in fact true. See, for example, Stephen Jay Gould, Ontogeny and Phylogeny (Cambridge, MA: Belknap Press of Harvard University Press, 1977).

17 On midrash as an alternative to either critical history or memory, see Michael A. Meyer, "Reflections on the Educated Jew from the Perspective of Reform Judaism," in Visions of Jewish Education, ed. Seymour Fox et al. (New York: Cambridge University Press, 2003), 149-77.

18 See Michael L. Satlow, How the Bible Became Holy (New Haven, CT: Yale University Press, 2014), 124-35. 
are gone... The Jew saw them all.... All things are mortal but the Jew; all other forces pass, but he remains. What is the secret of his immortality? ${ }^{19}$

Twain ends with a question-but the work has already been done. We can supply our own answers to the secret of the immortality of the Jewish people, but in fact, the power of his argument lies in how he explains the survival of the Jews as extraordinary, even implicitly miraculous.

Critical history retorts: there are no "secrets" of history, only unsolved problems. There can be no legitimate claims of immortality, and no appeals to the miraculous. History progresses in bits and pieces, each datum a piece of an endlessly complex puzzle. All historical events have precedents. Everything comes from something else. Everything evolves. Even the Jews and their supposed immortality is easily deconstructed: the Jews at any particular historical moment evolved from preceding civilizations and cultures, as did the Egyptians and the Babylonians and the Persians, and at any particular historical moment, gave rise to succeeding civilizations and cultures. Only in retrospect do we impose a narrative coherence on the story of the Jews. Unlike Mark Twain's puzzle, critical history has no corner pieces. For corner pieces would betray a belief in an overall pattern, a framework into which pieces, scattered hither and yon, would be slotted.

Such beliefs catapult us back to pre-modern thinking in which Jewish history, often inscrutable and impossible to predict, was marching zigzaggedly but inexorably toward ge'ulah, Redemption, guided by the invisible but unmistakable hand of HaShem.

To this critical history hoists a red card. The past can be no more and no less than the sum of its parts; meaning imposed rather than discerned as part of a Divine plan. Overarching schemes, teleological endpoints, frameworks of ultimate value, puzzle pieces forming an outline, shards casting a shadow whose outline points to something larger than so many bits of broken clay: such thinking violates critical history's ground rules. These rules scorn the pronouncement of grand schemes. They enjoin the practitioners to lower their sights. Yet, we might wonder, with the historian David N. Myers, whether the "obsessive demand to situate every historical datum in a discrete local context precludes the possibility of enduring meaning." ${ }^{20}$ Local contexts do not a coherent story make.

19 Mark Twain, “Concerning the Jews," Harper's Magazine, March 1898, http://legacy.fordham.edu/halsall/mod/1898twain-jews.asp.

20 Myers, Resisting History, 5. 
To the student who connects Shoah to T'kumah, echoing Soloveitchik's belief that the founding of the State of Israel was a "point along the eschatological pathway of Jewish history," we should answer that the words "eschatology" and "history" are incompatible in the same sentence. ${ }^{21}$ Eschatology implies the very framework of meaning that critical history abjures. There can be no foundational assumptions in critical history other than a Lockean commitment to empiricism and Popperian commitment to falsification. ${ }^{22}$ If the student persists, we may tell him that the jury's out on whether God exists, noting that such a question is not for the history class, anyway. What we can say, however, is that even if God does exist, He plays no role in history. In the Jewish history classroom, God is dead.

In this regard, Jewish history has a status no different than the study of Irish history, Hindu history, or the history of the New Orleans bayou. Critical history must play by the metaphysical rules of the natural sciences. And here, we move from the more general point about the absence of overarching meaning to a more specific point about theological assumptions. In other words, if it is true that Mark Twain's question about the secret of the immortality of the Jew is out of order, then it is even more true that a theistic answer to the question - that God is the answer to the immortality of the Jew-is beyond the pale. Brad Gregory, a Catholic historian at Notre Dame, observes that any appeal to God-in-History or God-as-Prime Mover must be regarded as "social, political, anthropological, psychological, economic, or natural because by definition there is nothing more for it to be." 23 Or as Dipesh Chakrabarty puts it, critical history-indeed the entire edifice of Western science-pivots on the assumption "the human is ontologically singular, that gods and spirits are 'social facts,' that the social somehow exists prior to them." ${ }^{4}$ People invent their gods. Or as we might say in Hebrew, Bereishit bara ha'adam et ha-elohim, "In the beginning, man created God."

21 "Destruction" and "Rebirth" are typically used in tying the events of the Holocaust to the birth of the State of Israel; see David Myers's summary of the position of Rabbi Joseph B. Soloveitchik (1903-1993) in Myers, Resisting History, 159.

22 Postmodernism has done a real number on this position, but the challenges from hermeneutics are also powerful. See Hans-Georg Gadamer, "The Problem of Historical Consciousness" in Interpretative Social Science: A Second Look, ed. Paul Rabinow and William M. Sullivan (Berkeley: University of California Press, 2001).

23 Brad Gregory, "The Other Confessional History: The Secular Bias in the Study of Religion," History and Theory 45, no. 4 (2006): 137.

24 Dipesh Chakrabarty, Provincializing Europe: Postcolonial Thought and Historical Difference (Princeton: Princeton University Press, 2000), 16. 
At this juncture, we must ask whether critical history is really as value-free as it claims. Gregory thinks not. He asserts that critical history carries its own "undemonstrable metaphysical beliefs" that can neither be affirmed nor denied using the empirical tools of modern social science. ${ }^{25}$ Indeed, he likens the absolutism of critical history, one that a priori denies truth to all religious claims, to the practice of church history, where the terminus of every historical investigation was known in advance. Just as church history embraced unassailable first principles, Gregory argues, so does modern science. In the academy, a commitment to "metaphysical naturalis $[\mathrm{m}]$ and cultural relativis $[\mathrm{m}]$... contend that religion is and can only be a human construction." 26

A God-less narrative is taken for granted in historical writing. Chazan, for example, writes 1,500 words on teaching history in Jewish schools without mentioning God. ${ }^{27}$ Richard White, the esteemed Stanford historian, dismisses his late mother's devout faith in short order: "I am a historian. I don't believe in transcendence. There is only the everyday." 28 White plainly admits his assumptions. In most historical writing, the same assumptions go without saying. There are exceptions, to be sure; the eminent Columbia University historian Richard Bushman, a Mormon and scholar of Mormonism, comes to mind. But in the main, a historian who embraced God in any causal scheme would be laughed out of the American Historical Association (AHA).

As Jewish educators, we are faced with a conundrum. Many of us have encountered students who see God behind every waving blade of grass, a stance that blocks the path of serious intellectual engagement with the past. Why even bother probing the causes of historical events, or the decisions of historical actors, if the answer is always God? But the alternative-banishing God from the history or allowing Him a cameo role and only then with the asterisk of "spiritual history" - seems equally unpalatable. Can there be a course that steers between dogmatic belief and absolutist disbelief?

Gregory thinks so. He proposes a way of thinking about religious claimswhat he calls "metaphysical neutralism"- which neither affirms them as first principles nor dismisses them out of hand:

25 Gregory, "The Other Confessional History," 137.

26 Ibid., italics in the original.

27 Chazan, "Faith and Critical Jewish History," 50-53.

28 Richard White, Remembering Ahanagram: Storytelling in a Family's Past (New York: Hill and Wang, 1998), 40; quoted in Gregory, “The Other Confessional History," 136. 
To reject the partisan religious convictions of traditional confessional history does not force one to adopt the metaphysical naturalism of secular confessional history. Instead, an approach that is metaphysically neutral neither privileges a particular tradition or specific religious claims, nor does it imply that scholars of religion must conduct research as if no religious claims could be true. ${ }^{29}$

A variation of metaphysical neutralism was examined in a symposium organized by the journal Historically Speaking in 2008. ${ }^{30}$ Under the title of "abundant history," Robert Orsi reviewed the events in Lourdes, France, when in 1858 the fourteen-year-old Bernadette Soubirous allegedly witnessed the appearance of the Virgin Mary. Historians have since explained away Marian apparitions using any variety of reasons: as a calculated attempt by the Papacy to centralize power; as a pretext by the secular state to justify the expansion of its transportation system (increasing taxes and using the excuse of transporting pilgrims to a far-flung village in the foothills of the Pyrenees); or by employing a Freudian framework that attributes the phenomenon to women's need to "experience vicariously the fulfillment of their desire for sexual contact with, and a baby from, their fathers." 11

What would happen, asks Orsi, if historians considered the possibility of Marian apparitions as examples of the "transcendent breaking into time," not unlike a burning bush that was not consumed or a divine voice endorsing the halakhic interpretation of Rabbi Eliezer rather than his opponent Rabbi Yehoshua? "Any claim that natural laws are necessarily exceptionless," notes Gregory, "is a dogma beyond the possibility of empirical confirmation."32

Gregory cites the philosophical critiques of Hume's dismissal of miracles to justify his position. ${ }^{33} \mathrm{I}$, however, understand metaphysical neutralism in a

29 Gregory, “The Other Confessional History," 147.

30 See Robert Orsi, "Abundant History: Marian Apparitions as Alternative Modernity," Historically Speaking (September-October 2008), 12-16.

31 Michael P. Carroll, The Cult of the Virgin Mary: Psychological Origins (Princeton: Princeton University Press, 1986).

32 Brad Gregory, "Back to the Future: A Response to Robert Orsi," Historically Speaking (September-October, 2008), 21.

33 Gregory cites among other works, J. Houston, Reported Miracles: A Critique of Hume (New York: Cambridge University Press, 1994); David Johnson, Hume, Holism, and Miracles (Ithaca: Cornell University Press, 1999); and John Earman, Hume's Abject Failure: The Argument Against Miracles (Oxford: Oxford University Press, 2000). I am relying on Gregory's reading here, not my own. 
slightly different way. I see it as an act of humility that has a place in the Jewish school.

To reiterate, I am explicitly not addressing the students who, on the first day of class, dogmatically assert that all events in Jewish history can be explained as the will and design of HaShem. Such students may believe that they are providing an answer to historiographical questions, but they are making a category error. Hashgacha peratit, divine intervention in the details of life, is a theological principle, rather than an historical explanation. Students who do not understand this have not fully grappled with discipline of history as its unique way of thinking. ${ }^{34}$

Rather, I take up the case of the student who has gotten As during the year, who is able to corroborate documents and pinpoint where the evidence stops and speculation begins. This student is able to explain how the Jews survived the Babylonian exile by regrouping at Sura and Pumbedita; how they outlived the Romans by fleeing to Yavneh; how they weathered the Arab invasions by adjusting to Dhimmi status; how they survived the Crusades and the Inquisition by converting to Christianity and secretly keeping their Judaism in the basement; how they responded to the pogroms by turning to Zionism; and how the sh'erit ha-pletah, the escaped remnant of the people, proved that even the modern technology of genocide has limits. This student's sure hand and quick mind can explain every affliction and every act of resilience of the Jewish people by weaving together local contexts and situating circumstances in a defined temporal framework. But at the end of the year the student is filled with disquiet. It is this student who on the last day of class brings up the quotation by Mark Twain and asks, "What should I think about this?" Is there nothing more to our history than the concatenation of isolated events? Is that the secret to the Jews' "immortality"? Are we forbidden to suggest that there might be some force beyond what reason can comprehend that motivates the course of Jewish history?

What would happen if we were to respond that critical history can do many things but that it, too, has limits? Can there be no discussion in the Jewish school, in the Jewish school's history class, about what we might call "points along the eschatological pathway of Jewish history"? Must the Jewish history classroom embrace one of secularism's deepest and least reflected upon assumptions? If so, then what makes learning Jewish history in a Jewish school different from learning American history in a public school? Is there not room for a small dose of humility in the face of the limits of knowledge,

34 I am indebted to Jonah Hassenfeld for helping me think about this issue. I admit, however, only to a partial understanding of what he was trying to teach me. 
as that enterprise is constituted and verified in the academy? Indeed, the Biblical minimalism of Israel Finkelstein and Neil Asher Silberman, on which Wolpe based his drash, has not fared well of late. ${ }^{35}$ As science repeatedly teaches us, we cannot affirm the null hypothesis. The absence of evidence is not evidence of absence. What is historical revisionism if not the admission that our cocksureness would have benefitted from a moment of silence?

What are the aims of learning history in the Jewish school and who gets to set them? ${ }^{36}$ From the vantage point of critical history, the answer of how to learn history differs only topically from approaches in a secular context. In the public school, we dissect different accounts of the Battle of Lexington, how myth has shrouded this event, how invented tradition makes its way into American lore, its zenith coming in the form of a postage stamp depicting a battlefield scene that contradicts all available evidence. ${ }^{37}$ From such investigations, students learn evidence-based reasoning, how historical argument is crafted and evaluated, and how to be more critical readers and evaluators of historical events. I have spent a good part of my career trying to understand how learning this kind of history-as opposed to rote memorization of names and dates - can be applied in a wide variety of contexts and sustained by teachers who work under the most difficult conditions. ${ }^{38}$

I have long argued that history, well taught, sharpens the mind. But surely this aim does not exhaust the justifications for history's place in the curriculum. An earlier rationale, one prominent among the framers of the American Constitution, is that engagement with the past offers moral tutelage. ${ }^{39}$ History exposes us to acts of courage and heroism. We meet figures who inspire us to lead better, bolder, and more meaningful lives.

35 Israel Finkelstein and Neil Asher Silberman, The Bible Unearthed (New York: Free Press, 2001). For an update, see Robert Draper, "Kings of Controversy: Was the Kingdom of David and Solomon a Glorious Empire-or Just a Little Cow Town? It Depends on which Archaeologist You Ask," National Geographic, January 8, 2015, http://ngm.nationalgeographic.com/2010/12/david-and-solomon/draper-text.

36 I am indebted to Daniel Marom for gently but persistently imploring me to address this issue over the many years of our friendship.

37 See Sam Wineburg, Historical Thinking and Other Unnatural Acts: Charting the Future of Teaching the Past (Philadelphia: Temple University Press, 2001); Sam Wineburg et al., Reading Like a Historian (New York: Teachers College Press, 2001).

38 Teresa Watanabe, "L.A. Unified Adopts Free History Curriculum from Stanford University," Los Angeles Times, November 27, 2014, http://www.latimes.com/local/education/la-mehistory-stanford-20141126-story.html\#page=1.

39 See David Tyack, "Ways of Seeing, An Essay on the History of Compulsory Schooling," Harvard Educational Review (Fall 1976). 
Such aims crashed and burned during the tumultuous years of the 1960s, when America convulsed with race riots, the Feminist and Antiwar movements, and the profound social changes that rocked every area of American life. Hero debunking became a national pastime. Thomas Jefferson was a slave owner and probably a rapist; Woodrow Wilson, who tirelessly fought to create the League of Nations, an unrepentant racist; FDR, a philanderer.

Like so many other sacred cows, the idea that history could provide moral instruction fell victim to a hermeneutic of suspicion, reaching its apex in Howard Zinn's A People's History of the United States, a relentless unmasking of the hypocrisy of practically any figure who had ever been praised in a traditional textbook. Zinn did not abandon moral judgment but gave it a new meaning. More than anything else, the study of history demanded an accusing finger to mete out moral judgments. J'accuse became the order of the day. ${ }^{40}$

Moral judgment, however, fertilizes the hubris of posterity. Robert Tracy McKenzie, chair of the history department at Wheaton College, "the Evangelical Harvard," takes up the question of moral judgment in his book, The First Thanksgiving, a work that overturns much of what we have grown up thinking about what happened between Pilgrim settlers and the indigenous people they encountered on their arrival in the "new world."41

While teaching about Pilgrims at Wheaton, McKenzie found his Christian students as ready to condemn the hypocrisy of Pilgrims as their secular counterparts were to vilify President Truman for his decision to drop the bomb. His students were quick to indict the Pilgrims for their grim and unyielding notions of right and wrong, and their sacred rush to pillory, literally, anyone who thought otherwise.

I recently encountered similar moral outrage among a group of Jewish students at Stanford, with whom I had a conversation about Ari Shavit's book, My Promised Land. We were discussing his chapter on Ein Harod, and how members of the kibbutz resorted to trickery, dishonesty, subterfuge and every means possible to remove their Arab neighbors from adjoining propertyone of the first acts, if you will, of Palestinian displacement. Shavit's book allowed these college students, many of whom but a semester away from positions at Google, Twitter, Booz Allen and McKinsey, to affirm twenty-first century values of fairness, anti-racism, and a commitment to social justice for all. They flexed their accusing finger at the pioneers of Ein Harod. "We

40 See Sam Wineburg, "Undue Certainty: Where Howard Zinn's A People's History Falls Short," American Educator 37 (2012-13): 27-34.

41 Robert Tracy McKenzie, The First Thanksgiving: What the Real Story Tells Us about Loving God and Learning from History (Downers Grove, IL: InterVarsity Press, 2013). 
would've known better, felt deeper, and acted more righteously than our ancestors," they seemed to say.

Moral judgment makes for lousy history. It's an even lousier tool for tikkun ha-middot, the never-ending process of human perfection and growth toward decency. Moral judgment, writes McKenzie, "renders a verdict but requires nothing of the knowing heart." ${ }^{2}$ McKenzie proposes moral reflection as an alternative, in which our meeting with those who come before us is an attempt to understand who we are. This meeting requires that we "make ourselves vulnerable to the past." 43 It obliges us, in the words of David Harlan, to engage in a "conversation with the dead about what we should value and how we should live." 44 At stake in this encounter is not the judgment of our predecessors' blemishes, but an attempt to hold a mirror to our own faces. This mirror does not whisper that we are the fairest of them all but calls on us to examine our foibles and reflect on what we consider to be the source of ultimate meaning. Moral reflection for these Stanford careerists would have had them consider not just the failings of their great-grandparents, but to consider what their ancestors gave up. What did it mean for young people their own age, armed with degrees from the finest European universities, to sacrifice their own personal ambitions and bind themselves to a collective mission of the Jewish people? And not just for ten days on an air-conditioned bus?

My son's question launched me on this quest but I end with more questions than when I started. I remain uncertain about what to say to Raphael, now twenty-four, working in Iowa as an AmeriCorps team leader. But recently, I was cheered to learn that in responding to difficult questions from youngsters at a Passover table, I am not alone.

The novelist and Hebraist, Jonathan Safran Foer, recently explained what motivated him to undertake a new translation of the Haggadah. He recounts a story from his own family Seder, when at the end of the night he was asked by his six-year-old son if Moses was a "real person." Foer, too, was taken aback. But his response hints at the humility that should be our aim.

"I don't know," he told his son, "but we're related to him." 45

42 Ibid., 182.

43 McKenzie, The First Thanksgiving, 182.

44 David Harlan, The Degradation of American History (Chicago: University of Chicago Press, 1997), 206. On a related point, see the important statement coming from hermeneutics, Deborah Kerdeman, "Pulled Up Short: Challenging Self-Understanding as a Focus of Teaching and Learning," Journal of Philosophy of Education 37: 293-308 (2003).

45 Jonathan Safran Foer, "Why a Haggadah?" New York Times, March 31, 2012, http://www. nytimes.com/2012/04/01/opinion/sunday/why-a-haggadah.html?pagewanted=all\&_r=0. 


\section{Bibliography}

Carroll, Michael P. The Cult of the Virgin Mary: Psychological Origins. Princeton: Princeton University Press, 1986.

Chakrabarty, Dipesh. Provincializing Europe: Postcolonial Thought and Historical Difference. Princeton: Princeton University Press, 2000.

Chazan, Robert. "Faith and Critical Jewish History: A Complex Relationship." HaYidion Nurturing Faith (2010), 50-53.

Derrida, Jacques. Limited Inc. Evanston, IL: Northwestern University Press, 1988.

Draper, Robert. "Kings of Controversy: Was the Kingdom of David and Solomon a Glorious Empire—or Just a Little Cow Town? It Depends on which Archaeologist You Ask." National Geographic, January 8, 2015. http://ngm.nationalgeographic.com/2010/12/david-and-solomon/draper-text.

Earman, John. Hume's Abject Failure: The Argument Against Miracles. Oxford: Oxford University Press, 2000.

Evans, Richard. In Defense of History. New York: W. W. Norton and Company, 1999.

Finkelstein, Israel, and Neil Asher Silberman. The Bible Unearthed (New York: Free Press, 2001).

Foucault, Michel. "Nietzsche, Genealogy, History [1971]." In The Foucault Reader. Edited by Paul Rabinow. 76-100. New York: Pantheon, 1984.

Gadamer, Hans-Georg. “The Problem of Historical Consciousness.” In Interpretative Social Science: A Second Look. Edited by Paul Rabinow and William M. Sullivan. 103-60. Berkeley: University of California Press, 2001.

Gregory, Brad. "Back to the Future: A Response to Robert Orsi." Historically Speaking (September-October, 2008), 20-22.

. "The Other Confessional History: The Secular Bias in the Study of Religion." History and Theory 45, no. 4 (2006): 132-49.

Haeckel, Ernst. Generelle morphologie der organismen [General Morphology of the Organisms]. Berlin: G. Reimer, 1866.

Harlan, David. The Degradation of American History. Chicago: University of Chicago Press, 1997.

Haskell, Thomas. Objectivity is Not Neutrality: Explanatory Schemes in History. Baltimore: Johns Hopkins, 1998.

Houston, J. Reported Miracles: A Critique of Hume. New York: Cambridge University Press, 1994.

Johnson, David. Hume, Holism, and Miracles. Ithaca: Cornell University Press, 1999.

Kerdeman, Deborah. "Pulled Up Short: Challenging Self-Understanding as a Focus of Teaching and Learning." Journal of Philosophy of Education 37 (2003): 293-308. 
"L.A. Rabbi Blasted for Fifth Question: Was There Really a Passover Exodus?" Jewish Telegraphic Service, April 27, 2001. http://www.jta.org/2001/04/27/jewish-holidays/passover/l-arabbi-blasted-for-fifth-question-was-there-really-a-passover-exodus.

McKenzie, Robert Tracy. The First Thanksgiving: What the Real Story Tells Us about Loving God and Learning from History. Downers Grove, IL: InterVarsity Press, 2013.

Meyer, Michael A. "Reflections on the Educated Jew from the Perspective of Reform Judaism." In Visions of Jewish Education. Edited by Seymour Fox, Israel Scheffler, and Daniel Marom, 149-77. New York: Cambridge University Press, 2003.

Myers, David N. Resisting History: Historicism and its Discontents in German-Jewish Thought. Princeton: Princeton University Press, 2003.

Niebuhr, Gustav. "Religion Journal; A Rabbi’s Look at Archaeology Touches a Nerve." New York Times, June 2, 2001.

Novick, Peter. That Noble Dream: The "Objectivity Question" and the American Historical Profession. New York: Cambridge University Press, 1988.

Orsi, Robert. "Abundant History: Marian Apparitions as Alternative Modernity." Historically Speaking (September-October 2008): 12-16.

Rabinow, Paul. “Introduction.” In The Foucault Reader. Edited by Paul Rabinow, 3-30. New York: Pantheon, 1984.

Safran Foer, Jonathan. "Why a Haggadah?" New York Times, March 31, 2012. http://www. nytimes.com/2012/04/01/opinion/sunday/why-a-haggadah.html?pagewanted=all\&_r=0.

Satlow, Michael L. How the Bible Became Holy. New Haven: Yale University Press, 2014.

Twain, Mark. "Concerning the Jews." Harper's Magazine, March, 1898. http://legacy.fordham. edu/halsall/mod/1898twain-jews.asp.

Tyack, David. "Ways of Seeing, An Essay on the History of Compulsory Schooling." Harvard Educational Review 46: 3 (Fall 1976): 355-89.

von Ranke, Leopold. Geschichten der romanischen und germanischen Völker von 1494 bis 1535

(History of the Latin and Teutonic nations, 1494-1535). Leipzig: Reimer, 1824.

Watanabe, Teresa. "Doubting the Story of Exodus." Los Angeles Times, April 13, 2001.

"L.A. Unified Adopts Free History Curriculum from Stanford University," Los Angeles

Times, November 27, 2014. http://www.latimes.com/local/education/la-me-history-stanford-20141126-story.html\#page $=1$.

White, Hayden. Metahistory: The Historical Imagination in 19th-century Europe. Baltimore, MD: Johns Hopkins University, 1973.

White, Richard. Remembering Ahanagram: Storytelling in a Family's Past. New York: Hill and Wang, 1998.

Wineburg, Sam. Historical Thinking and Other Unnatural Acts: Charting the Future of Teaching the Past. Philadelphia: Temple University Press, 2001.

. "Undue Certainty: Where Howard Zinn's A People's History Falls Short." American Educator 37 (2012-13): 27-34.

Wineburg, Sam, Daisy Martin, and Chauncey Monte-Sano. Reading Like a Historian. New York: Teachers College Press, 2001.

Yerushalmi, Yosef Hayim. Zakhor: Jewish History and Jewish Memory. New York: Schocken, 1989. 